\title{
Political, Legal, Religious Reforms of the Altyn Orda in Its Early Years
}

\author{
Abdunaim Seidmukhammed \\ Ph.D Student, Faculty of Islamic Studies, Egypt University of Islamic Culture Nur Mubarak, Kazakhstan \\ Post address: 73 al-Farabi Ave., Almaty, Republic of Kazakhstan, 050016; E-mail: seid_abdunaim@mail.ru
}

\begin{abstract}
Absattar Derbisali
The Institute of Oriental Studies of the Ministry of Education and Science of RK, Doctor of Philological Sciences, Professor, 050040 Kazakhstan, Post address: 73 al-Farabi Ave., Almaty, Republic of Kazakhstan, 050016; E-mail: nurmubarak2013@mail.ru.
\end{abstract}

Omirzhanov Yesbol,

Professor of al-Farabi Kazakh National university, Address:131 shmidt street, Almaty, Kazakhstan

E-mail: yesbol_1981@mail.ru

\section{Daulet Kozhambek}

PhD sdudent, Faculty of Social Sciences, Ahmet Yesevi University, Kazakhstan, B. Sattarhanov Ave 29

Turkestan, Republic of Kazakhstan, 161200, Ahmet Yesevi University; E-mail: kozhambekov@mail.ru

\section{Doi:10.5901/mjss.2015.v6n6s1p561}

\section{Abstract}

This study scientifically analyzes the influence of Islam in political independence movements, more specifically its effect on the historic Mongol Altyn Orda, and presents new insight on the political and legal reform processes in Kazakhstan within a historical context. In particular, this study will look at the religious dispute that took place between the descendants of Genghis Khan's eldest son Jochi following the death of Batu, Jochi's second son and his successor, who founded the Orda in his name. In this conflict, Berke, Batu Khan's brother, eventually won the political struggle that erupted after Batu's death. His support of Islam caused the permanent division of his grandfather Genghis Khan's empire, but it can also be shown that his choice of religion strengthened the independence of the Altyn Orda.

Keywords: Religion, Islam, Christians, Yasa, Shed-Jadid, the Caliph, militarism, tolerance, state, ulys, empire.

\section{Introduction}

The lands conquered by Genghis Khan were divided after his death among the four sons born to his wife Borte (Egorov V.L., 1985). Jochi, the eldest son, stood to inherit, had he been alive (he died six months before his father), the land between the rivers Irtysh and Ural, as well as those further west "as far as the hooves of Mongol horses have trodden," and the Pontic-Caspian steppe southward from the Aral Sea to the Amu Darya River (northern Khorezm).

Because these lands were given to his father, Jochi, the region was called through Batu's life the "Ulus of Jochi" ("ulus" translates to "realm"). The share of empire that went to Genghis' second son Chagatai, called the Chagatai Khanate in his life, included Transoxiana (the region between the Amu Darya and Syr Darya rivers in modern Uzbekistan) and ancient Kashgaria, both of which comprised the Kara-Khitan Khanate that Mongol military commander Jebe had conquered in Genghis' name. Genghis' third and favorite son, as well as his successor, Ügedei, inherited as a personal domain present western Mongolia and the lands dominated by the Tarbagatai mountains in between present China and Kazakhstan. The youngest son, Tolui, was given the Mongol homeland as well as the largest body of warriors with which to defend it. This division of the Mongol Empire into "ulus" was considered to be the will of Genghis Khan (Kulpin E.S. 2008).

Of the realms of the four sons of Genghis and Borte, three inherited territory in present Kazakhstan. The Ulus of Jochi extended over the whole of the Dasht-i-Kipchak khanate, which was completely conquered after the Battle of the Kalka River near present Mariupol, Ukraine, in 1223. From this base of power, the Altyn Orda would control for two centuries much of the same area that the Eurasian Economic Community represents today. 
For Kazakhstan, it is very important that its citizens know the history of the state, and how the descendants of Genghis Khan and his eldest son Jochi exerted their political will, and created the administrative divisions both internally and externally at the end of Genghis' great empire. In particular, the separation of the Ulus of Jochi from Qaraqorım into an independent Alytn Orda greatly affected the nation's history. This followed the conversion of Berke Khan to Islam, an event that can be argued to be one of the seminal events of Kazakh culture. Noting the importance of the Altyn Orda on the history of the world, it follows that the legacy of this era should be extensively studied.

Some of those who have already contributed to the world's understanding of this area of history include Ibn alAthir, Ibn al-Wasil, Ibn al-Omari Kasir, Ibn al-Qalqashandi, Ibn al-Asqalani Arabshah, Wetemish Wahab, and Ali Yazdidin. Russian Imperial era authors, whose writings are so important that for any serious study of the region a review is inevitable, include such oriental scholars as llya Berezin, Gordiy Sablukov, Vladimir von Tiesenhausen, Nikolay Veselovsky, Vasily Bartold, and George Vernadsky. During Soviet times, various aspects of the history of the Altyn Orda were reviewed by such respected researchers as Boris Grekov, Alexander Yakubovsky, Mahamet Safargaliev, German Alexeyevich Fedorov-Davydov, Ali Alizadeh, Klavdiya Antonovna Pishchulina, and Vadim Leonidovich Egorov.

\section{Ityn Orda as a State}

\subsection{Forming of Altyn Orda as a state.}

Genghis Khan's invasion of Central Asia pitted his warriors not only against the Qidan and Khorezm. He also faced the Dasht-i-Kipchak khanate and a dozen nomadic Turkic tribes situated on the Ustyurt Plateau between the Amu Darya, Aral Sea, and the Kara-Bogaz-Gol inlet on the Caspian Sea. The establishment of the Mongol Empire in the region brought together Central Asian Tengriism, European Christianity, and Middle Eastern Islam together in a single culture. However, the religious and cultural relationships between the Turkic tribes led to a gradual prevalence of Islam. Indeed, the Turkic tribes under the Ulus of Jochi would eventually universally adopt Islam.

Under Batu Khan, the political regime and the economic situation proved effective at keeping a resilient peace between sordid ethnicities and different religions during the early years of the Altyn Orda (Ulus of Jochi). In Sarai Batu, the seat of power for the Ulus of Jochi, Mongols lived peacefully alongside subjugated Kipchaks, Circassians, Russians, and Byzantines, according to Egorov (Egorov V.L., 1985). At the very beginning, the rulers of the Altyn Orda did not prescribe a specific religious belief, which positively influenced the expression of individual religious denominations within its reach.

The nomads that lived within the Ulus of Jochi, as a result, didn't hold any one belief. They followed such diverse religions as Tengriism, Nestorian Christianity (particularly among the Kereits and Naimans that populated present western Mongolia), Orthodox Christianity, and Islam.

This religious diversity was highly unusual. Even the Khazar Empire, a people caught at the crossroads of religions on the northern shores of the Caspian that eventually fell to the rising Kievan Rus, ultimately selected Judaism as their singular state religion (E.S. Kulpin, 2008). Their adherence was so fierce that even their last remnants, the Mountain Jews of Qirmizi Qasaba, a village located across the Gudiyalchay River from Quba in the Caucasus of Azerbaijan, still follow it today (Kulpin E.S. 2008).

The Mongols, meanwhile, took a totally different approach. "The Tatars of the time would not have been notable except for their resistance to accepting (a state) religion," wrote Montesquieu about the tolerance between faiths during the reign of Batu Khan (Charles Louis de Montesquieu. 2004). The cultural policy of his regime was to concentrate people of the same beliefs in different regions: they moved the Jewish Khazars to the lands of the Amu Darya, the Zoroastrians and other Persian faiths to Persia, the Christians to the lands held by the Slavs, and Islam to the nomadic Turkic people. This religious freedom enjoyed by the people under the Altyn Orda opened the way to uniquely peaceful exchanges of culture between East and West.

\subsection{Seperation of Altyn Orda from Qarakurum}

Batu Khan, the leader who united the Mongols of the Altyn Orda, or the Ulus of Jochi, died in 1256 . He ordered as his dying wish that his eldest son, Sartaq, who had organized state affairs for years before his father's death, be seated on his throne at Sarai. However, Sartaq's rule did not last very long. He died suddenly before 1258.

Looking over the existing historical evidence of events that followed Sartag's death, one can say that the rise of Berke, Batu's brother, as the new ruler of the Ulus of Jochi marked the emergence of politically-oriented religious groups. According to "The collection of materials related to the history of the Altyn Orda," Berke and Sartaq had strong religious 
differences. It is said that when Sartaq rose to power in Sarai, Berke openly laid a rival claim to the throne. Hearing this, Sartaq refused to even greet his uncle when met him on the way back from being confirmed as Khan of the Altyn Orda by Mongke, the Khagan, or Great Khan of the Mongol Empire. Berke took great offense at the disrespect his nephew showed him, his older relative. He was even more upset after asking through a messenger why he was snubbed, as Sartaq's reply was that Berke was a Muslim, and that he believed in the Christian faith, and that to meet with him would displease his God. It is said that Berke was so upset that he prayed to Allah, "If the faith of Muhammad corresponds with the truth, then take vengeance upon Sartaq!" Within three days, according to a contemporary Muslim writer, Sartaq fell ill and died.

Historians researching the Altyn Orda period have confirmed that Berke was indeed a Muslim and Sartaq was most likely a Nestorian Christian. Arabic scholar Amin al-[Holiday] suggested that Berke was a Sufi "murid" or "committed one" who went by the name of Al-Bakharzi. He asserted that a Sheikh converted Batu's brother to Islam in 1252, well before the death of the aging Khan, when his caravan passed through the thriving Ural River trading city of Sarai-Dzhuk ("Little Sarai"). Bartold, meanwhile, wrote that Sartaq came under the influence of Christianity during the reign of Batu.

Many researchers speculate that their differences in religion caused the uncle and nephew to break-up from their previously good relationship. One such researcher who studied the deeper religious and spiritual processes that took place in the era of the Altyn Orda was Z. Zhandarbek, who observed that religion indeed spurred a spiritual crisis. "All said that it was still in the time of Batu Khan that an internal family conflict began on the basis of religious and cultural beliefs. Berke and his cousin Mongke Khan, the fourth Khagan of the Mongol Empire, failed to listen to Sartaq Khan's preferences and they did what they wanted, (Z. Zhandarbek. 2005) which resulted in the internal conflict within the Altyn Orda."

To clarify the cause of this political crisis in the Altyn Orda, a chronological, historical, and empirical analysis was employed.

When Sartaq died, Khagan Mongke appointed Sartaq's 10-year-old son Ulaghchi to succeed him. Mongke Khan entrusted the state to Batu Khan's most senior widow, the Khatun Borakchin. However, Ulaghchi did not live long after his coronation, and indeed Berke's supporters may have forced the boy's abdication. As a result, Berke Khan, grandson of Genghis Khan, became the first of his ruling descendants to accept Islam. His ascent to the throne of the Ulus of Jochi in 1257 demonstrated a power to establish greater independence from Mongke's court at Qaraqorım (Kazakh Soviet Encyclopedia. Volume I, 1972). It can be said that Berke's religious views influenced his personal political decisions, which moved him away from other descendants of Genghis Khan.

\section{Altyn Orda Independent State.}

\subsection{Berke Khan splits the Altyn Orda from Qaraqorim}

Berke Khan's actions to separate the Altyn Orda from Qaraqorım, rendering it effectively an independent state, is easily investigated using similar analytical methods involving chronology, synthesis, and anti-synthesis.

In general, Berke Khan's decision to establish a new and separate state was influenced by several factors. The following factors had perhaps the greatest impact on Berke cutting ties from Qaraqorım.

The first factor was that when Kagan Mongke died in 1259, Berke sided with Ariq Boke, the youngest son of Tolui, against his older brother Kublai and Hulagu in the struggle for succession. As these two were absent from Qaraqorım when Mongke died, Ariq Boke managed to briefly ascend as Khagan of the Mongols. By 1264, Kublai forced his younger brother to surrender at Shangdu (also known as Xanadu). Although Ariq Boke was pardoned by his older brother, many of his supporters were killed. Naturally, when Kublai summoned Berke to come to his new court and discuss his loyalty to Ariq Boke, Berke declined, saying that he had plenty of problems in holding his own regime together. This appeared to be one of the signs that he was eventually going to refuse to recognize the suzerainty of his cousin as Khagan.

The second factor was that Berke opposed Hulagu's military invasion (as directed by Mongke Khagan) of the Muslim Caliphate and the creation of a new llkhanate in its stead. Hulagu easily succeeded in taking Persia and Baghdad despite Berke's opposition. In 1256, Hulagu crossed the Amu Darya River with his army and defeated Persian defenses in the Transoxiana, immediately taking 40 of their strongest fortresses. Without stopping, his army continued to advance and by early 1258, it had destroyed the capital of the Islamic Caliphate in Baghdad, killed the Caliph al-Musta'sim, and plundered his enormous wealth. This sent enormous shock waves through the Muslim world. The Sultan of Egypt responded to the immediate threat by leading a force that defeated Hulagu's lieutenants at Ain Jalut, but rather than a counter-offensive, this was considered little more than a delay to an eventual assault against the Mamluks. After 1260, Sultan Zahir al-Din Baibars sent an envoy to Berke Khan asking for help to preserve the Muslim world together. This 
resulted in a religious alliance between Mamluk Egypt and the Ulus of Jochi against Hulagu's Ilkhanate, later sealed by marriage between the children of the Sultan and Berke Khan. This action seemed to verify that the new ruler of the Altyn Orda would not recognize the rule of the Toluids. Indeed, Berke seemed to indicate that he may have held a separate claim on Qaraqorım. In any case, the action demonstrated the religious factor behind Berke's declaration of independence from the rest of the Mongol world.

The third factor can be found in looking at the law of the "Great Yasasy" that Genghis Khan set forth, which said that any loot taken in any war would be divided in five parts. Two of the parts would be given to the Great Khagan in Qaraqorım, two of the parts would be given to the troops, and the last of the fifths would be given to the family of the Khan who led the war. When Hulagu took Baghdad, the trophies that were eventually sent to Berke by the Khagan displeased him. This economy-based complaint contributed to driving the Ulus of Jochi to actually declare war on Hulagu's Ilkhanate. Further, the suspicious deaths of Berke's lieutenants Tutar, Balakan, and Kuly, who were ordered by Mongke Khan against Berke's wishes to take part early in the invasion of Persia, inspired the Khan's outrage against Hulagu. When Berke sent secret envoys to Hulagu later on, the only response that Hulagu provided was to have them killed (Batyr-uly Bahitty., 2005). All of these events served to separate the two rulers, beneficiaries of Genghis Khan's legacy, and badly divided the Mongols, leading both parties to defend their own interests against each other.

The fourth factor involved a dispute over territory in Transcaucasia. In 1223, Genghis Khan assigned the regions occupied today by Azerbaijan and Georgia to the Ulus of Jochi (History of Kazakhstan. Volume I, 1998 Atamura) However, they were only conquered by the Mongols under Hulagu Khan in his invasion of Persia. Berke refused to cede these to the Ilkhanate, and Hulagu refused to cede these to the Ulus of Jochi, even though both he and his rival were bound to do so as grandsons of Genghis Khan. As such, a political rivalry between Genghis Khan's descendants was brought into sharp relief in the struggle for Transcaucasia.

\subsection{Reforms in Altryn Orda.}

The value of Berke Khan's Islamic political and legal reforms in the Altyn Orda are best understood by applying the principles of time and space, relying specifically on empirical and cultural studies.

When Berke Khan ascended to the throne in Sarai, the Ulus of Jochi entered a new era. More precisely, the Altyn Orda became a separate political power emergent from a formerly subordinate khanate as a result of its ruler adopting Islam as a state religion. Earlier, this report comprehensively reviewed the political reasons that the Ulus of Jochi abandoned Qaraqorım. These do not need further emphasis, but all of the factors that facilitated the Altyn Orda leaving the Mongol world in the time of Berke Khan do require exploration to develop a complete understanding of the situation.

Berke Khan had initiated new changes in the way that his state viewed its independence from Qaraqorım. During his reign, enmity between the descendants of Genghis Khan sprang up as it became clear that they could not establish a system that allowed them to share their conquered possessions. The first ruler of the Altyn Orda was Batu Khan, second son of Jochi. He regarded himself as neutral with respect to religion. However, Batu's son, Berke, regarded the acceptance of Islam as a more appropriate religious path for his people, and under his rule religious processes took on a greater role in the domestic and foreign policy of the Ulus of Jochi.

While on the throne in Sarai, Berke Khan spent a lot of energy changing the culture within the Altyn Orda, developing an internal and external management structure to meet his political ambitions. The ruler changed the internal leadership of the country away from the strictly non-religious nature of Genghis Khan and his followers and toward something that provided greater subordination to the center of the empire. Berke even developed a larger military, creating an administrative system that oversaw groups of 10,100, and 1,000 soldiers, strengthening his army (Safargaliev M.G. 2005). In the administration of his state, he called on Islamic religious scholars to advise him, with a view toward turning the Ulus of Jochi gradually into an Islamic state. Where foreign Muslims settled, the study of Islam began very quickly as they built mosques and madrassas - places of worship and places of education (Religion and beliefs Dasht-i-Kipchak in XIII-XIV centuries, 2005).

When Berke Khan converted to Islam after his encounter with a caravan in Sarai-Dzhuk, he built a new city called Sarai-al-Jadid just a little ways above the original Sarai (a name that means "palace" - Sarai Batu, or "Batu's Palace", was sometimes called Sarai-al-Maqrus, the "Blessed Palace"). This new capital would be renamed after Berke became Khan as Sarai Berke (Kazakh history. "Zhalyn" Almaty 1993) Sarai Batu was situated on the Akhtuba waterway of the Volga delta, about 120 kilometers north of present Astrakhan, while Sarai-al-Jadid was probably located some 300 kilometers north of Astrakhan, or 80 kilometers east of Volgograd, also on the Akhtuba waterway. Undoubtedly, the move of the capital was taken to better inspire the Altyn Orda to a more Muslim perspective, as the capital contained many Muslim ornamentations. This was clearly influenced by the political and religious cooperation between the Ulus of Jochi 
and Mamluk Egypt (M. Mustafa Ziada., 1934- 1942) The Sultans of Egypt are documented as having provided funds to send hewers of stone and architects to help design mosques for the project. Along with the mosques and madrassas, though, these architects built public baths, toilets, water pipes, and fountains (Kulpin E.S. ). Gradually, these people who once defined themselves as the conquerors of lands became masters of the craft of needlework as the city developed a wholly different culture (Religion and beliefs of Dasht-i-Kipchak in XIII-XIV centuries, 2005).

One of the first major changes Altyn Orda underwest was the adaption from a Turkic nomadic existence into one of a settled culture. The process of urbanization of Altyn Orda started during the reign of Batu Khan, the older brother of Berke Khan. In 1242, Batu Khan took up the construction of Sarai-Batu, his capital city along the Edil River. At first, SaraiBatu served, before its construction was completed in 1254, as a military and administrative center for the lands the Golden horde ruled. Later, it became a vast city with varied architecture and a population of more than 75,000 . Besides the governor's residence, there were barracks for the regular armed forces emplaced there, caravanserai - or places for caravans to stay, and trading centers that met the needs of the general public. The population of the city consisted of merchants and craftsmen. The rulers of the "Saray al-Makhrusa" built water pipes to provide local people with drinking water. For sanitation, they built underground sewers and drainage channels. A public bath was opened as well. 14 . (Kazakh history. "Zhalyn" Almaty 1993), (M. Mustafa Ziada., 1934- 1942).

The reason the Mongols chose to build a new capital at the mouth of the Edil River, and not select another ancient city as an administrative center, was that the site was well situated between the Caucasus in the southwest, the Danube River in the west, the Irtysh River and ibir-Sibir in the northeast, the ancient Kunya Urgench trade city in the southeast, the Aral Sea in the east. This new capital was well-situated along the main caravan route for east and west trade. The peculiarity of the geopolitical location of the "Saray al-Makhrusa" led to further economic and political independence for the Ulus of Jochi from their overlords in Qaraqorum.

Along with the establishment of a new capital for the Altyn Orda, Batu Khan, successor and son of Jochi, recovered other cities after they were destroyed during conquest (such as Khorezm and Derbent). (Egorov V.L., 2005). As a result, in the structure of their empire, they developed administrative centers and new different industries. The conquering nomads not only dealt with cattle breeding, but also they encouraged cultural development imported from cities near their own administrative centers.

\subsection{Tax policy of Berke Khan}

To improve the economic position of the state, Altyn Orda introduced a taxation system. Governors for agriculturalists and cattle-farmers were ordered to introduce new tributes, called Qalan and Qapshuyr. Qalan taxation imposed a one-tenth charge given to the public treasury, taken from all crops that farmers raised and brought to market. Qapshuyr taxation imposed a one-in-one hundred fee for each animal raised by cattle herders. City merchants and craftsmen were charged this same sort of fee as well. To provide the huge army of the Mongol horde with necessary provisions, it was obligatory to contribute all kinds of commodities, especially cattle. Such tributes provided to the military were called Ulaq.

The enormous revenue brought into the state treasury grew also from customs duties, fees imposed on the manufacturing industry, and storage costs imposed for animal-herder's use of ambars and public scales. Fines were also imposed for tax avoidance. Charges were made on the use of bridges, mills, and ploughs. Even the governors had defined specific fees for the use of irrigated lands, pasture, water, fisheries, forests, and horticultural resources (Gaziz, 1994). Other cases involving provisions for soldiers included fees given in grains taken from other "avariz" duties. In general, there were 20 different types of fees that were extracted from the population (Kazakhstan tarihy, 2000). The purpose of these various types of taxation, however, were not to exploit the local population as much as it was to advance the vision of the Altyn Orda to more efficiently use taxes to stimulate the revenue improvement of the state.

\section{Conclusion}

To a degree, the Altyn Orda was considered a usurped regime by distant countries that were under its control, as without support from the larger Mongol empire, the Golden Horde was simply regarded as incapable of sustaining control of its empire indefinitely. Berke Khan's personal ambitions and the influence of Islam on the Ulus of Jochi were the driving factor behind independence from Qaraqorım. Berke was older than Hulagu Khan, and as such he felt his seniority afforded him the right to securing more profit from the occupied territories in today's Iran and Syria. Additionally, when the Ilkhanate seized Transcaucasia, neither Azerbaijan nor Georgia had belonged to either power, though it had been promised to the Altyn Orda of Batu Khan. These differences became the casas belli between the two descendants of Genghis Khan. 
Berke, as noted earlier, converted to Islam, but Hulagu retained his Tengrian faith, and this religious component only added fuel to the conflict. Certainly it spelled an end to the unifying factor of religious pluralism that had been a legacy of Genghis Khan's empire.

Batu Khan, successor son of Jochi, who himself was accepted by Genghis Khan as his firstborn son by his first wife Borte (she was pregnant with Jochi throughout her 8-month captivity under her Merkit kidnappers early in their marriage, and as a result, no one can be sure that Jochi was actually Genghis' biological son), conquered Eastern Europe and set its maximum extent within the Ulus of Jochi, a realm he named for his father in order to maintain his claim on his throne at Sarai Batu. Berke Khan, Batu's brother, separated the Ulus of Jochi from Qaraqorım and formed it into an independent state. The Altyn Orda under his reign became not only an independent state, but also a patron of the true religion, Islam. It also created a new higher culture and developed into a great political and economic power. Under Berke, the Altyn Orda had, in fact, risen to the level of an empire. The full contribution of the Altyn Orda to human culture and civilization has not yet been fully studied. Indeed, the most visible contribution of the Mongols to Kazakhstan, the advancement of Islam into Central Asia, is perhaps the clearest conclusion that can be drawn from this report.

\section{References}

Batyr-uly Bahitty. Egypt State Mamluks Dasht-i-Qıpşaq connections XIII-XV centuries. Research. Almaty: Economy, 2005.

Charles Louis de Montesquieu. Laws of the spirit. "Three Kyan". 2004. 517 p

Chronicle of Ahmad ibn Ali al-Makrizi, entitled Kitab al-Suluk li-marifat duwal al-muluk, ed. by M. Mustafa Ziada. I-II, Cairo, 1934- 1942

Egorov V.L. Historical Geography of the Altyn Orda in XIII-XIV centuries. - M .: Nauka, 1985.

Egorov V.L. Zolotaya Orda. M.GMY, 2005, 7-8 pp.

Fedorov-Davidov G.A. Zolotoordinskie goroda Povolzhie - Moscow. MGU. 1994, 10-11 pp.V.

Gaziz The history of the Tatars. M. 1994

History of Kazakhstan. Volume I, 1998 Atamura

Kazakh history. "Zhalyn" Almaty 1993

Kazakh Soviet Encyclopedia. Volume I, 1972

Kazakhstan tarihy, Volume 2, 2000. Almaty Atamura baspasy

Kulpin E.S. Altyn Orda: The fate of generations. Insan publishing. Moscow 2008

Kulpin E.S. Altyn Orda: The fate of generations. Insan. Moscow

Religion and beliefs Dasht-i-Kipchak in XIII-XIV centuries // History and culture of Altyn Orda. - St. Petersburg: Slavia. 2005. pp 3-7

Religion and beliefs of Dasht-i-Kipchak in XIII-XIV centuries // History and culture of the Altyn Orda. - St. Petersburg: Slavia. 2005. pp 37.

Safargaliev M.G. Collapse of Altyn Orda // At the hides of Continents and civilization. - Moscow: "Iman. 1960

Zhandarbek Z. Yasawy time and Kazakh community. Almaty. 2005. Country-chronicle. 


\title{
The Responsiveness of Bureaucracy in Implementing Free Health Care Service in Sidenreng Rappang Regency, Indonesia
}

\author{
Basra \\ Suratman \\ Rifdan \\ Andi lhsan \\ Universitas Negeri Makassar, Makassar, South Sulawesi, Indonesia, Jln. Bonto Langkasa, Kampus UNM Gunung Sari \\ Postal Code 90222; basramakka@gmail.com, suratmannur@yahoo.com, rifdan@unm.ac.id, andiincan@gmail.com
}

\section{Doi:10.5901/mjss.2015.v6n6s1p567}

\begin{abstract}
The aim of this research is to find out and analyze the implementation of bureaucracy responsiveness principle in implementing free health care service policy in Sidenreng Rappang regency based on: bureaucracy's attitude in responding complaints, service in providing health care, and response in involving and empowering service user in health care service system. The result of this research concludes that the implementation of bureaucracy responsiveness principle in implementing free health care service in Sidenreng Rappang Regency is not fully optimal. It is proven by: (1) Health Official Bureaucrat shows friendly and committed attitude toward the cleanliness, togetherness, and disciplines in providing health care service and in accordance to the implementation of bureaucracy responsiveness principle in providing health service; (2) Properly respond user's complaints related to the planning program, but the response to complaints related to program implementation, monitoring and evaluation of the program is not maximally administered or less responsive; (3) Empowerment/service user involvement, including participative program from all the stakeholder component gives positive impact and implication toward the bureaucrat's working performance in executing free health care service.
\end{abstract}

Keywords: responsiveness, bureaucracy, policy implementation

\section{Introduction}

Health Care Service provision is a fundamental right for all Indonesian people. It is immensely important for Indonesian government to implement good governance principles in executing public service to its people, including health service, fair treatment, responsiveness and service efficiency. Such goal can only be achieved by building holistic and sustainable health care service which meant to improve health awareness, willingness and ability to live healthy to all of Indonesian people.

Responsiveness is one of important public service dimension, an indicator of service related to apparatus responsiveness to any society complaints and needs that demand service as regulated in the law. Bureaucracy poor ability in responding can trigger the sense of truth crisis. High economic and politic dynamic due to truth crisis are things beyond the ability of bureaucracy to anticipate which make the lives of the society even worse and uncertain. Initiative and creativity of bureaucracy in responding is not enough to decrease the crisis and its impact. Society expects quick response toward the crisis are left with disappointment because the bureaucracy response tends to be reactive and less effective. Various problems in the center and regional area still unresolved without comma or even remain untouchable which make the society lost their trust easily toward the ability of the bureaucracy to deal with the crisis.

The afore separate mentioned phenomena above successfully describe how fragile society's trust is and government legitimacy. The reason behind this fragility is that the government along with its bureaucracy has failed their society to be a capable institution which protects and fight for public interests and needs. Power oriented institution has made the bureaucracy growing more irresponsive and insensitive toward their society call for help. Recent domination exposed by the bureaucracy in both economic and politic aspects have created many distortions in executing public services which tends to escalate and worsen the happening economy and politic crisis even more.

This research is conducted to find out and analyze the implementation of bureaucracy responsiveness principle in 
implementing free health care service policy in Sidenreng Rappang regency based on: bureaucracy's attitude in responding complaints, service in providing health care, and response in involving and empowering service user in health care service system.

\section{Review of Related Literatures}

Etymologically, bureaucracy means "power behind the table". According to Lance Castle bureaucracy is "paid and functioned people in government body". Bastard bureaucrat, a short mean sentence used by Blau and Meyer, (2000, $p$. 3 ) the "bureaucracy" term used by Blau and Meyer does not refer to government inefficiency and infectivity, because in their opinion that is not the real meaning of "bureaucracy".

Blau (2000, p. 6), the term bureaucracy is synonymously used with inefficiency, although Bureaucracy is actually a powerful institution with the capability to increase the potential capacity toward good and bad things, because basically bureaucracy is a neutral rational administration instrument in bigger scale. Bureaucracy has the power to make the imperialistic expansion easily and exploit the economy to destruct underdeveloped countries and the needy.

Bureaucracy is intended as a rationally approved authority system by many rules. According to Widodo (2002, p. 50), bureaucracy has vital roles in organizing the government and development. By that vital roles, bureaucracy is classified into three different things namely bureaucrat, politic, and profession. Bureaucracy as a profession refers to particular occupation which requires certain special requirement as opposed to other kinds of existing profession, means that position in bureaucracy can only be seated by those who possess expertise in specific field. Service Bureaucracy is basically an organization which directly interacts with the society. In line with Service Bureaucracy, Thoha (2003, p. 78) stated that the service provided by the government bureaucracy has the exclusivity to use the authority and power within the institution to force the entire civilian to obey the approved the rules and regulations.

Responsiveness as an indicator of service is related to the ability of the government apparatus in responding society`s needs. Dwiyanto (2008, p. 51), explained responsiveness as the organizational capability to know the needs of the society, arrange and prioritize the agenda and service, as well as develop public service programs to meet the need and aspiration of the society. In brief, responsiveness in this case refers to the harmony of service and the demands of the society toward the given service.

An approach policy implementation approach is introduced by Van Meter and Van Horn called $A$ Model of the Policy Implementation (1975, p. 463). This model suggested that policy implementation goes linear with politic decision, executor and public policy performance. This model explains that policy performance is influenced by several related variables, those are; (1) standard and policy target/benchmark and goal of the policy; (2) resources; (3) characteristic of the organization in charge; (4)executor's attitude; (5) inter-organizations communication and programs; (6) social environment, economy, and politic.

\section{Research Method}

The design of this research is descriptive qualitative. This research analyze bureaucracy's responsiveness in implementing free health care service policy in Sidenreng Rappang Regency.

The sources of the data in this research are bureaucrat apparatus and the society as the public user (stakeholders) who are experienced and educated about the health condition in Sidenreng Rappang regency, based on their main job and function which consists of: (1) Primary data collected from informants statements, and other deliberately gathered information related to the focus of the research through observation and interview. Those informants including Head of Health Official, Head of Clinic, Medic and Nursing Practitioners, Health Official Staffs, Society Respected Figure, onGovernment Organization (NGO); (2) Secondary data sources are relevant documentation in the form of written documents (local regulation, literary books, scientific writing, national and international published journal, printed mass media or electronic/internet, main program development, strategic plan, and annual plan), pictures, and statistical data about the development of public health service, main instrument of the research is the researcher per se, aided by other research instruments such as; observation guidance, interview guidance, and written document.

\section{Research Findings and Discussion}

The research findings of the implementation of bureaucracy responsiveness principle in implementing free health care service in Sidenreng Rappang are as follow: 